\title{
Dynamic regulation of integrin activation by intracellular and extracellular signals controls oligodendrocyte morphology Inger Marie Olsen ${ }^{1,2}$ and Charles ffrench-Constant*1
}

Address: ${ }^{1}$ Departments of Pathology and Medical Genetics, University of Cambridge, Tennis Court Road, Cambridge CB2 1QP, UK and ${ }^{2}$ Centre for Basic Psychiatric Research, Aarhus University Hospital, Skovagervej 2, DK-8240 Risskov, Denmark

Email: Inger Marie Olsen - Inm@psykiatri.aaa.dk; Charles ffrench-Constant* - cfc@mole.bio.cam.ac.uk

* Corresponding author

Published: 12 November 2005

BMC Biology 2005, 3:25 doi:10.1 I86/1741-7007-3-25
Received: 17 June 2005

Accepted: 12 November 2005

This article is available from: http://www.biomedcentral.com/l74I-7007/3/25

(C) 2005 Olsen and ffrench-Constant; licensee BioMed Central Ltd.

This is an Open Access article distributed under the terms of the Creative Commons Attribution License (http://creativecommons.org/licenses/by/2.0), which permits unrestricted use, distribution, and reproduction in any medium, provided the original work is properly cited.

\begin{abstract}
Background: Myelination requires precise control of oligodendrocyte morphology and myelin generation at each of the axons contacted by an individual cell. This control must involve the integration of extracellular cues, such as those on the axon surface, with intrinsic developmental programmes. We asked whether integrins represent one class of oligodendrocyte cell-surface receptors able to provide this integration.

Results: Integrins signal via a process of activation, a conformational change that can be induced either by "outside-in" signals comprising physiological extracellular matrix ligands (mimicked by the pharmacological use of the divalent cation manganese) or "inside-out" signalling molecules such as R-Ras. Increasing levels of outside-in signalling via the laminin receptor $\alpha 6 \beta I$ integrin were found to promote oligodendrocyte processing and myelin sheet formation in culture. Similar results were obtained when inside-out signalling was increased by the expression of a constitutively-active RRas. Inhibiting inside-out signalling by using dominant-negative R-Ras reduces processes and myelin sheets; importantly, this can be partially rescued by the co-stimulation of outside-in signalling using manganese.

Conclusion: The balance of the equilibrium between active and inactive integrins regulates oligodendrocyte morphology, which is itself regulated by extrinsic and intrinsic cues so providing a mechanism of signal integration. As laminins capable of providing outside-in signals are present on axons at the time of myelination, a mechanism exists by which morphology and myelin generation might be regulated independently in each oligodendrocyte process.
\end{abstract}

\section{Background}

The process of myelination in the CNS requires a remarkable morphological transformation by newly-formed oligodendrocytes, with processes contacting and extending along each axon before elaborating a myelin membrane to enwrap the axon multiple times to create a sheath. This differentiation step is tightly controlled, as indicated by the formation of processes each with sufficient membrane for a sheath thickness that has a precise relationship with final axon diameter [1]. In order to ensure that the precise amount of myelin is formed at the right developmental stage and in the correct place, a key component of oligodendrocyte behaviour during myelin formation must be the integration of multiple extrinsic signals at the axon surface along with intrinsic programmes, such as autonomous developmental timers of differentiation. These 

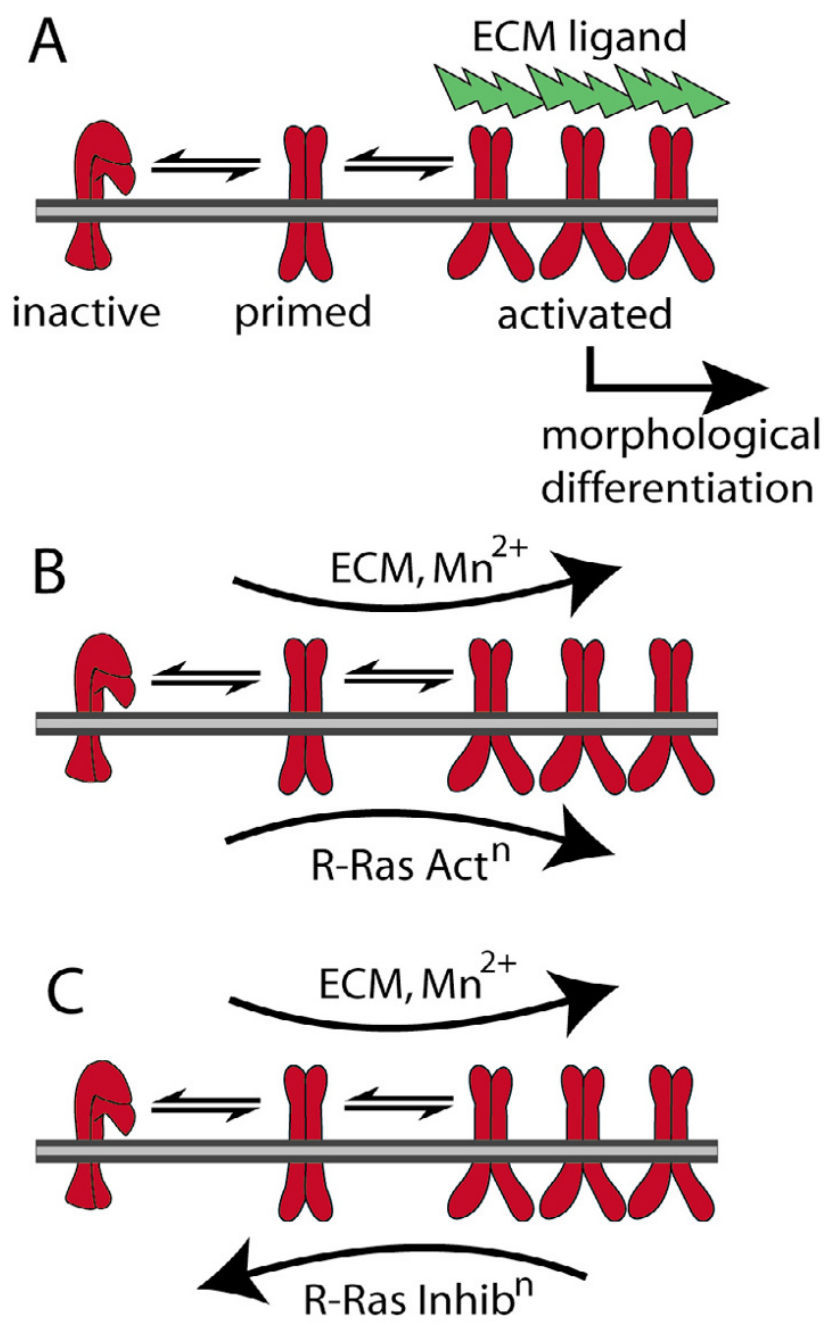

Figure I

Strategies for manipulating integrin activation in oligodendrocytes. Panel $A$ shows the equilibrium between 3 different conformations of integrin; inactive, primed and activated. Only the latter assembles a signalling complex and promotes morphological differentiation of oligodendrocytes, as manifested by complex processes and the formation of myelin sheets. Panel B shows the 2 methods used in this study to promote activation; outside-in signalling using high extracellular matrix (ECM) ligand concentrations or the divalent cation $\mathrm{Mn}^{2+}$ (results in Fig 2), and inside-out signalling using active RRas (Fig 3). Panel C illustrates the logic of the experiment shown in Fig 4 to confirm that integrins integrate these extracellular and intracellular cues, showing how outside-in signalling would be predicted to overcome the effects of RRas inhibition on oligodendrocyte morphology and myelin sheet formation.

points of integration are therefore important for our understanding of myelination and may facilitate the development of strategies to promote remyelination.
One important group of candidate integrative molecules are the integrins, the cell surface receptors of extracellular matrix proteins. Integrins comprise two transmembrane chains, termed $\alpha$ and $\beta$, with a ligand-binding site formed by the head domain of the two chains [2]. Recent work has established that integrins exist in at least three different confirmations on the cell surface, each in a dynamic equilibrium with one another (Fig 1A) [3-7]. Inactive integrins are folded over, have a low binding affinity for ligand and do not signal. Primed integrins are straightened, and bind ligand with higher affinity as a result of shape changes within the head domain. Activated integrins have bound ligand leading to receptor clustering, and have undergone a further shape change in the $\beta$ chain leading to separation of the two cytoplasmic domains, thereby allowing formation of the signalling complex (termed "outside-in" signalling). Since the change of shape can be transmitted across the membrane in either direction, activation can also be achieved by so called "inside-out" signals. These separate cytoplasmic domains and induce changes in the extracellular ligandbinding site that increase receptor affinity, leading to ligand binding, integrin clustering and signalling. As a result, integrin activation and formation of the signalling complex is regulated by the integration of both extrinsic ligand concentrations and the activity of (intrinsic) 'inside out' signalling pathways.

Oligodendrocytes express 5 integrins; $\alpha \mathrm{V} \beta 1, \alpha \mathrm{V} \beta 3, \alpha \mathrm{V} \beta 5$ and $\alpha \mathrm{V} \beta 8$ as well as $\alpha 6 \beta 1[8,9]$. In cell culture, the $\alpha \mathrm{V}$ integrins promote proliferation and migration $[10,11]$, while the laminin receptor, $\alpha 6 \beta 1$, promotes differentiation (as measured by myelin sheet formation) and survival $[12,13]$. In vivo, mice lacking $\alpha 6$ show increased apoptosis of newly-formed oligodendrocytes [14]. Transplantation of cells expressing dominant-negative $\beta 1$ integrins into focal demyelinated lesions in the adult rat reduced the extent of remyelination [15]. We therefore focused on $\alpha 6 \beta 1$ to examine the hypothesis that integrin activation provides a mechanism for the integration of extrinsic and intrinsic signals in oligodendrocyte differentiation. Our goal was to test two key predictions of the hypothesis (Fig 1B and 1C): (i) that either extracellular or intracellular signals regulating integrin activation can control oligodendrocyte morphology, and (ii), that the effects of inhibition of one class of signals could be partially overcome by stimulation of the other, so demonstrating integration of signals by the integrin.

\section{Results}

We have shown previously that laminin-2 substrates promote the formation of a differentiated morphological phenotype in oligodendrocytes, as evidenced by increased elaboration of processes and myelin sheets, and that $\alpha 6$ and $\beta 1$ integrin subunits are found throughout the proc- 
A
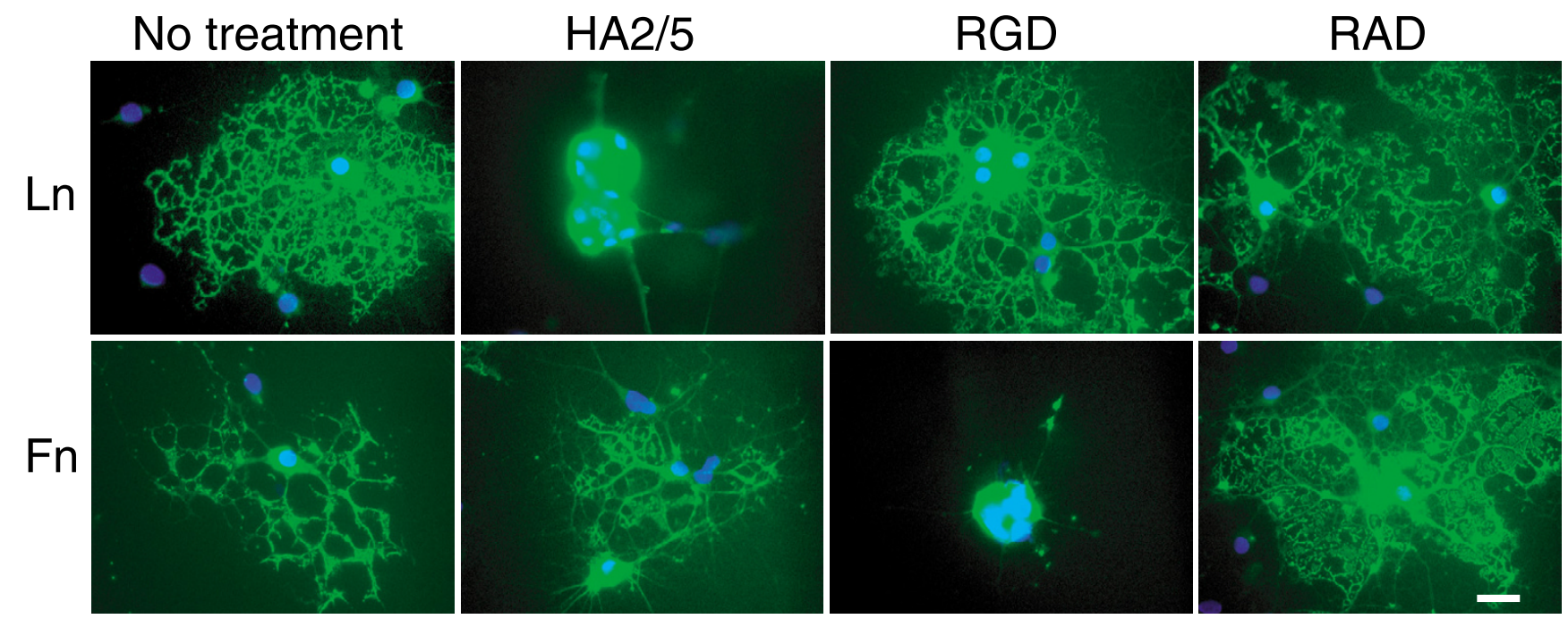

B

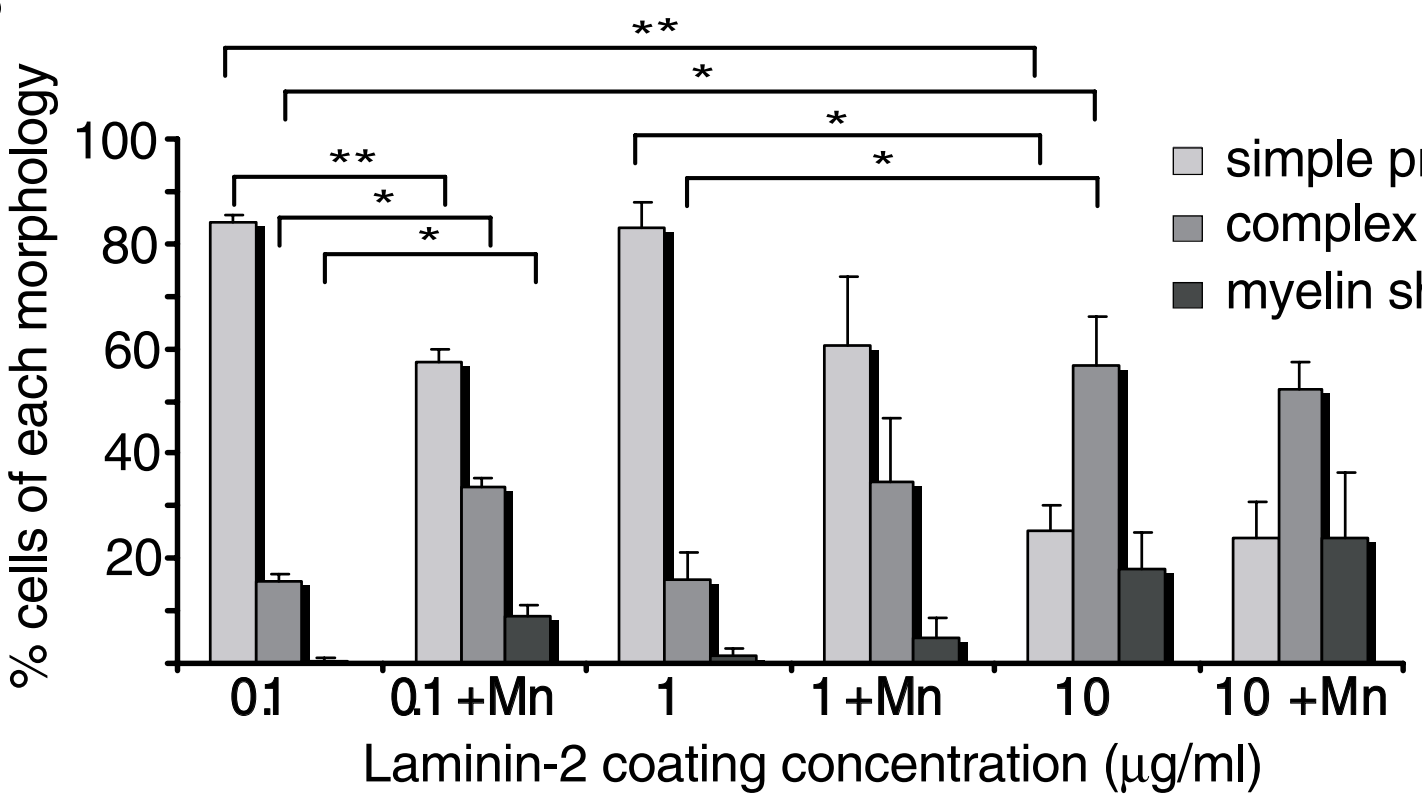

\section{Figure 2}

Outside-in integrin signalling in oligodendrocytes. Panel A shows that morphological differentiation of oligodendrocytes on laminin-2 requires integrins. A monoclonal anti- $\beta$ I integrin-blocking antibody $(\mathrm{Ha} 2 / 5)$ inhibits oligodendrocyte process formation on laminin-2 (Ln) but not fibronectin (Fn). In contrast, RGD peptides that block $\alpha \mathrm{V}$ integrins inhibit the morphological differentiation on Fn. No change is seen with control RAD peptides that do not perturb integrin function. Panel $B$ shows that integrin activation by outside-in signalling promotes differentiation. Increasing laminin- 2 concentrations are associated with greater process complexity and myelin sheet formation, with significant increases seen between I and I0 $\mu \mathrm{g} / \mathrm{ml}$. Mn ${ }^{2+}(\mathrm{Mn})$ also promotes differentiation, with significant effects seen at the lowest laminin-2 concentration $(0.1 \mu \mathrm{g} / \mathrm{ml})$. Note that the addition of $\mathrm{Mn}^{2+}$ has no significant effect on morphology at the higher laminin concentrations. Single and double asterix indicate significance levels of $p<0.05$ and $p<0.01$ respectively, calculated using Student's paired t-test. Scale bar in panel A is $20 \mu \mathrm{m}$.

ess network of oligodendrocytes [12]. To confirm that the change in phenotype was $\alpha 6 \beta 1$ integrin dependent (and can therefore be used as an assay of integration of insideout and outside-in signalling), oligodendrocyte morphol- ogy was analyzed in the presence of the monoclonal antibody Ha2/5 (that blocks $\beta 1$ integrins) and RGD peptides (that mimic the peptide recognition sequence within the extracellular matrix molecules recognised by $\alpha \mathrm{V}$ integrins 

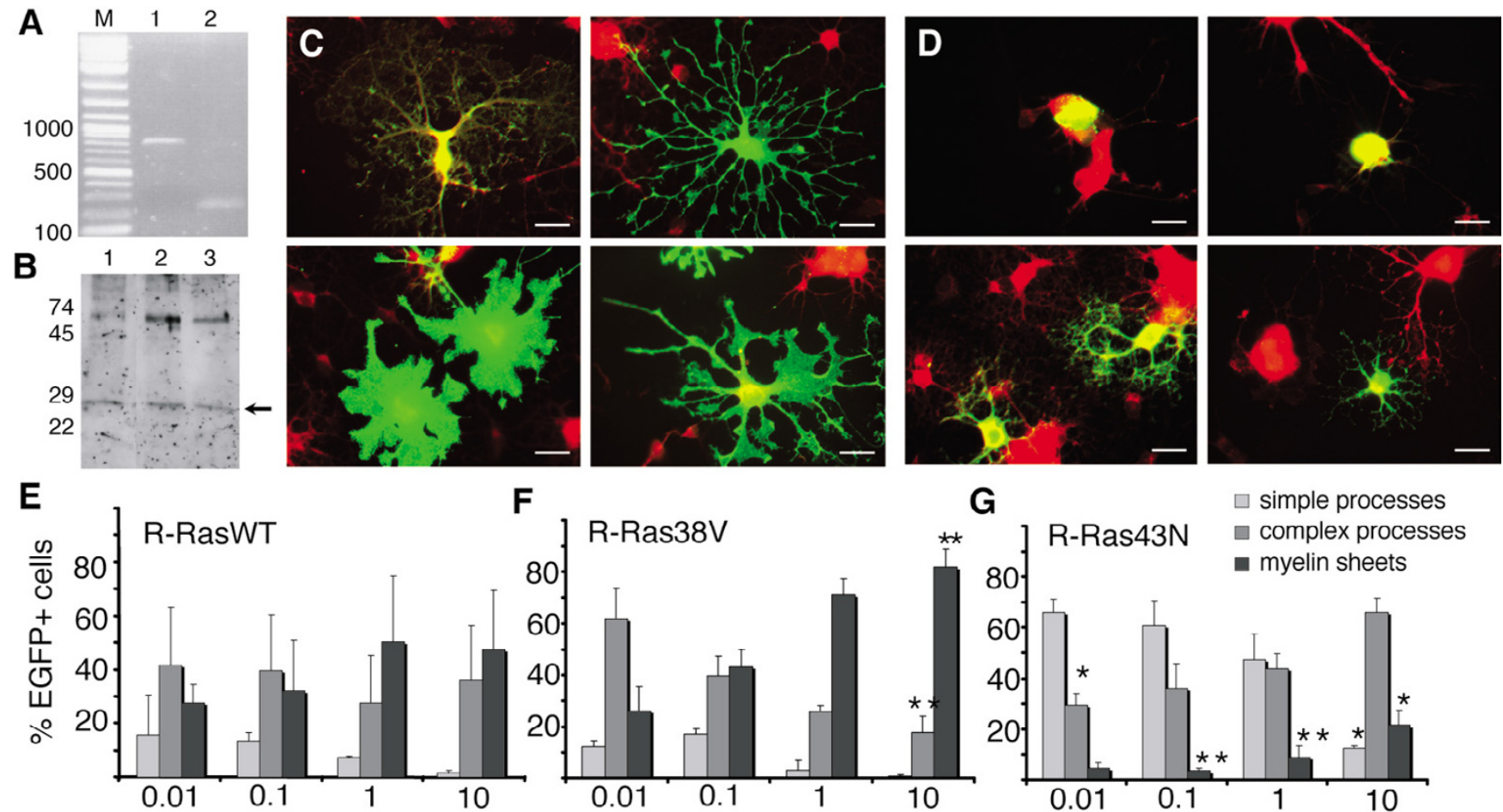

G
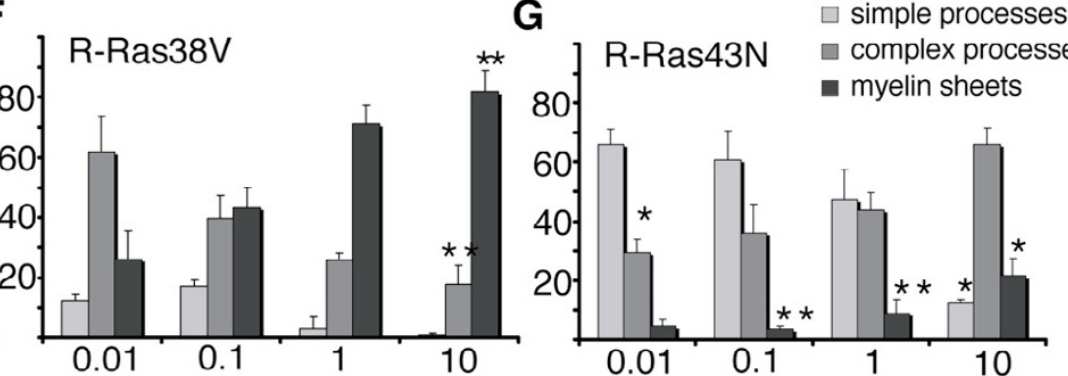

Laminin-2 coating concentration $(\mu \mathrm{g} / \mathrm{ml})$

\section{Figure 3}

Inside-out integrin signalling in oligodendrocytes. Panel A shows an RT-PCR experiment on cDNA obtained from cultured oligodendrocytes, grown as described in the Methods. Lane I - size markers (nt); lane 2 - ADAM9 (control); lane 3 - R-Ras. Panel B shows a western blot of lysates from 3 different sets of cultured oligodendrocytes (lanes I-3) using anti-R-Ras antibodies. All 3 lanes show a band at the predicted size $(23 \mathrm{kD})$ of R-Ras (arrow). Size markers (kDa) shown on the left. These 2 experiments therefore confirm that oligodendrocytes express R-Ras. Panel $C$ shows the effect of expressing constitutively active R-Ras (R-Ras38V) in oligodendrocytes, while Panel D shows the effect of expressing the dominant-negative R-Ras43N; all 4 micrographs in each panel show representative examples of transfected cells visualised by antibodies against EGFP (green) and CNPase (red). Note the different morphologies observed, with elaborate processes and large sheets seen in some cells expressing R-Ras38V and stunted processes in some expressing R-Ras $43 N$. The effects of R-Ras38V and R-Ras $43 N$ at different laminin-2 concentrations are quantified in Panels F and G, with control cells (expressing wild-type R-Ras) in these experiments shown in panel $\mathrm{E}$. These show the increased complexity of R-Ras $38 \mathrm{~V}$ cells at all laminin-2 concentrations when compared with wild-type cells, in contrast to the decreased complexity of the R-Ras $43 \mathrm{~N}$ cells. Single and double asterix indicate significance levels of $p<0.05$ and $p<0.0$ I respectively, calculated using Student's paired t-test. Scale bars in panels $C$ and $D$ are $20 \mu \mathrm{m}$.

and so block all the oligodendrocyte $\alpha \mathrm{V}$ integrins [16]). While confirming previous results with polyclonal anti- $\beta 1$ antibody, we also found that the monoclonal Ha2/5 antibody blocked morphological differentiation on laminin2 (Fig 2A). In contrast, this antibody had little effect on fibronectin substrates, which promote process outgrowth but not myelin sheet formation and on which the RGD peptide was an effective inhibitor (Fig 2A). Since $\alpha V \beta 1$ and $\alpha 6 \beta 1$ are the only $\beta 1$ integrins expressed on oligodendrocytes, and because RGD peptides would be expected to block $\alpha \mathrm{V} \beta 1$, we conclude that morphological differentiation leading to myelin sheet formation by oligodendrocytes on laminin-2 is $\alpha 6 \beta 1$-dependent.
To confirm that extracellular signals regulate oligodendrocyte morphology by activation of $\alpha 6 \beta 1$, oligodendrocyte precursor cells were plated on increasing concentrations of laminin-2 and allowed to differentiate into oligodendrocytes. Oligodendrocyte morphology was scored as having either simple (primary) processes only, complex (secondary and tertiary) processes or myelin sheets, reflecting the different changes associated with axon contact and sheath formation. Increasing the laminin-2 coating concentration from 1 to $10 \mu \mathrm{g} / \mathrm{ml}$ resulted in a significantly greater degree of morphological differentiation (Fig 2B). To exclude the possibility that this represented signalling by a second non-integrin receptor rather 


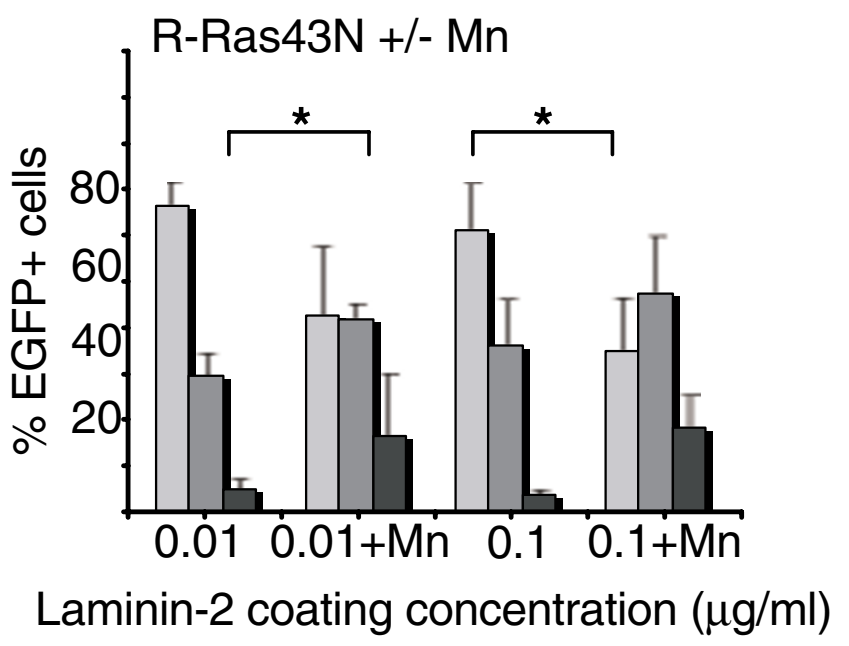

Figure 4

Outside-in integrin signalling rescues the effect of dominantnegative R-Ras43N. In the same set of experiments illustrated in Fig 3, Panel $\mathrm{G}$, addition of $\mathrm{Mn}^{2+}$ significantly increases oligodendrocyte complexity in the cells expressing dominant-negative R-Ras. ${ }^{*} p<0.05$.

than $\alpha 6 \beta 1$ integrin, we also examined the effect of adding $\mathrm{Mn}^{2+}$ to the tissue culture media. This divalent cation replaces the $\mathrm{Ca}^{2+}$ normally present in the integrin ligandbinding domain and activates the integrin as a result of the conformational changes associated with the substitution. At low coating concentrations of laminin-2 $(0.1 \mu \mathrm{g} /$ $\mathrm{ml}), \mathrm{Mn}^{2+}$ significantly increased morphological differentiation, but had no effect at higher concentrations (Fig 2B). This result would be expected if either high ECM concentrations ( $1 \mu \mathrm{g} / \mathrm{ml}$ and above) or $\mathrm{Mn}^{2+}$ were sufficient to activate the oligodendrocyte $\alpha 6 \beta 1$ integrins effectively, while lower ECM concentrations only elicited partial activation. Consequently, $\mathrm{Mn}^{2+}$ promotes further differentiation at low ECM concentrations (by activating those integrins not already activated by the ECM) but has no significant additive effect at the high ECM concentrations.

The effect of intracellular signalling pathways that regulate integrin activation was explored. Both RT-PCR and western blotting studies confirmed the presence of R-Ras in oligodendroglial cells (Fig $3 \mathrm{~A}, \mathrm{~B}$ ), shown to regulate integrin activation in other cell types $[17,18]$. To manipulate R-Ras signalling, transient transfections of primary oligodendrocyte precursor cell populations were used to express either wild-type (control) or mutant forms of RRas [19]. Expression of a constitutively active mutant form of R-Ras (38V) resulted in a dramatic increase in sheet formation by the oligodendrocytes (Fig 3C). Quantification revealed that this increase was significantly greater than that seen in cells expressing wild-type R-Ras at the highest laminin-2 concentrations tested, with $>80 \%$ of the cells expressing sheets at $10 \mu \mathrm{g} / \mathrm{ml}$ (Fig 3F).

Conversely, a dominant negative R-Ras construct (43N) reduced the degree of morphological differentiation seen in response to laminin-2 (Fig 3D). When compared with cells expressing wild-type R-Ras, the percentage of oligodendrocytes with a complex morphology was significantly reduced at laminin-2 concentrations above $0.1 \mu \mathrm{g} /$ $\mathrm{ml}$, with the percentage exhibiting a simple morphology correspondingly increased (Fig 3G). Together with the data using the constitutively-active R-Ras $38 \mathrm{~V}$, these results point to the presence on the surface of the oligodendrocyte of a dynamic equilibrium between inactive and activated $\alpha 6 \beta 1$ that can be displaced in either direction by manipulation of R-Ras signalling. Moreover, when considered with the experiments using high laminin-2 coating concentrations and/or $\mathrm{Mn}^{2+}$, they confirm our first prediction that either intracellular or extracellular cues regulating activation can control oligodendrocyte morphology.

To test the second prediction of the hypothesis that this equilibrium provides a mechanism for integrating intracellular and extracellular cues, we determined whether the effects of inhibiting activation by dominant negative RRas (an "inside-out" signal) could be overcome by stimulating activation using $\mathrm{Mn}^{2+}$ (an "outside-in" signal), as illustrated in Fig 1C. $\mathrm{Mn}^{2+}$ increased the extent of sheet formation, and decreased the percentage of cells with a simple morphology, in cells expressing the dominant negative R-Ras construct at the two lower laminin concentrations tested (Fig 4). Because $\mathrm{Mn}^{2+}$ acts directly on the integrin ligand binding domain, we can conclude that the increase in sheet formation reflects a direct effect on the integrin and therefore on the equilibrium between inactive and active integrins, rather than via modulation of separate downstream signalling pathways.

\section{Discussion}

These results show that the equilibrium between active and inactive integrins regulates oligodendrocyte morphology and myelin sheet formation. The balance of this equilibrium is determined by a combination of intracellular signals and extracellular ligand concentrations, with the two classes of signal integrated by individual integrin heterodimers. Manipulation of the equilibrium provides one mechanism by which both the number of myelin sheaths formed by an individual oligodendrocyte, as well as their thickness, could be regulated during CNS development.

To be relevant to myelination in vivo, our results require the presence of signals in the developing brain that can promote both outside-in and inside-out integrin signal- 
ling. We have shown previously that laminin $\alpha 2$ (the $\alpha$ chain present in the laminin trimers 2,4 and 12) is present on the surface of axons in embryonic brainstem at the time of myelination [14], extending a previous report of laminin $\alpha 2$ expression by Purkinje cells in the myelinating postnatal cerebellum [20]. Binding of this laminin would provide an outside-in signal, as shown in the experiments using increasing laminin concentrations. A number of different extracellular signals might trigger the intracellular pathways that promote inside-out signalling. For example, our previous work has defined a role for growth factors and their receptors in integrin activation via "inside-out" signalling. In studies on cell proliferation of oligodendrocyte precursors, $\alpha v \beta 3$ integrin was activated by PDGF [21]. Activation of $\alpha v \beta 3$ had been previously described in response to VEGF in endothelial cells [22], suggesting this might represent a general mechanism for integrin/growth factor interactions. Two other extracellular signalling systems, eph/ephrins and semaphorins, have also been shown to alter integrin activation [23-25]. Equally, the key intracellular components of the insideout signalling pathway are present in oligodendrocytes. We have reported here that R-Ras is expressed in oligodendroglia. Recent work has shown that the interaction of the cytoskeletal protein talin with the $\beta$ integrin cytoplasmic domain represents a final common pathway for the signals that promote activation [26], and we have also found that talin is expressed in oligodendroglial cells (Uli Forster and $\mathrm{C}$ ff-C, unpublished observations) consistent with such a role in these cells.

These observations show that there are multiple potential signalling pathways that might regulate the equilibrium of active and inactive integrins. Together with our present results, they support a model by which this equilibrium provides a dynamic means of integrating multiple signals to control the timing of myelination and the extent of myelin membrane. The model is based on the assumption that, under physiological conditions during normal development where growth factors are present in limiting concentrations, two classes of signals are required to generate sufficient numbers of activated integrins. So, for example, the laminin on the axon surface would be necessary for integrin signalling and myelination, but may not be sufficient without a further contribution to integrin activation from intracellular ("inside-out") signals. These "insideout" signals could be generated by growth factor signalling, or alternatively from intracellular pathways driven by autonomous developmental clocks [27], and would then effectively act as timers of myelination. Equally, while these intracellular signals may initiate the myelination process, the amount of myelin formed (and hence the number of wraps) would then be determined by the concentration of extracellular ligand on the axon surface, with higher concentrations increasing integrin activation and so the amount of myelin produced. A precedent for wrapnumber being determined by the concentration of axonsurface molecules is provided by the PNS, where transmembrane isoforms of neuregulin regulate Schwann cell myelination $[28,29]$. There is no evidence that laminins provide quantitative signals to the myelinating oligodendrocytes, but the observation that laminin- 2 deficient dy/dy mutant mice show an increased $G$ ratio (reflecting thinner myelin) in the CNS [30] would be consistent with such signals, and further studies are required.

\section{Conclusion}

Oligodendrocyte morphology is regulated at least in part by the balance of active and inactive integrins (Fig 1A). Such a model provides important insights into two aspects of oligodendrocyte biology. First, a single oligodendrocyte can myelinate multiple axons, and the thickness of each sheath (and therefore the amount of myelin membrane produced at the end of each process) is independently regulated by the axon it ensheaths. Clearly, this remarkable example of local control of cell-cell interactions cannot be regulated entirely by changes in transcription or translation initiated in the cell body. However, the control of integrin signalling by alterations of the equilibrium between active and inactive integrins provides a plausible mechanism by which integrin ligands on the axon could regulate membrane formation and morphological changes independently within each process. Second, one hypothesis for the failure of remyelination in MS (the dysregulation hypothesis) is that the loss of the coordination between promyelinogenic signals, rather than the loss of any one specific factor, prevents repair [31]. The possibility that integrative signalling molecules such as integrins might provide targets for drug therapies designed to promote remyelination by activation and promotion of signalling in the absence of the usual upstream cues therefore requires further investigation.

\section{Methods \\ Oligodendrocyte cultures}

Purified oligodendrocyte precursor cells were obtained from primary cultures of newborn Sprague-Dawley rat forebrains and were isolated by mechanical dissociation and differential adhesion as described previously [8]. The precursor cells were then plated on 8-well Permanox chamber slides (Nunc) pre-coated with fibronectin (10 $\mu \mathrm{g} / \mathrm{mL}$; Sigma) or laminin-2 $(0.01,0.1,1$ and $10 \mu \mathrm{g} / \mathrm{mL}$; Sigma human placental laminin) at 20,000 cells/well. For both the blocking experiments and the $\mathrm{Mn}^{2+}$ experiments, the cells were allowed to attach to the substrate for $2 \mathrm{~h}$ at $37^{\circ} \mathrm{C}$ before adding either blocking reagents or $\mathrm{Mn}^{2+}$. $\mathrm{Ha} 2 / 5$ antibody (PharMingen) was used at $10 \mu \mathrm{g} / \mathrm{mL}$, blocking peptides (RGD and RAD; Calbiochem) were used at $0.1 \mu \mathrm{g} / \mathrm{mL}$ and $\mathrm{Mn}^{2+}\left(\mathrm{MnCl}_{2} \cdot 4 \mathrm{H}_{2} \mathrm{O}\right.$; Sigma $)$ was 
freshly prepared and used at $50 \mu \mathrm{g} / \mathrm{mL}$. After 3 days of differentiation in SATO medium [8] at $37^{\circ} \mathrm{C}, 7.5 \% \mathrm{CO}_{2}$, cells were fixed with $4 \%$ paraformaldehyde for $15 \mathrm{~min}$ at room temperature. The cells were permeabilised and blocked in a one-step procedure with $10 \%$ normal goat serum (NGS, Sigma) and 0.1\% TritonX-100 (NBS Biologicals) in PBS for one hour at room temperature prior to immunostaining.

\section{Transfection}

After 10-12 days in vitro, the forebrain cultures were rinsed twice with DMEM (Sigma) supplemented with $10 \%$ fetal bovine serum (Sigma) and subsequently transfected overnight with the following constructs; pEGFPC1/R-Ras-wt, pEGFP-C1/R-Ras-38V and pEGFP-C1/RRas-43N using FuGene 6.0 (Roche). The R-Ras constructs have been previously described [19], and were a kind gift of Prof Alan Hall (UCL, London, UK). They were recloned into the pEGFP-C1 vector (Clontech) following digestion with BamHI and XbaI. The cells were then washed three times with DMEM (10\% fetal bovine serum) and $24 \mathrm{~h}$ later they were plated onto laminin-2 substrates as described above at 40,000 cells/well. The cells were differentiated for 3 days before fixation, permeabilisation and blocking in preparation for the immunostaining.

\section{Immunostaining}

Cells were washed three times with PBS and were incubated with appropriate dilutions of the primary antibodies in a buffer of PBS, $1 \%$ NGS and $0.1 \%$ Triton X-100 for $1-2 \mathrm{~h}$ at room temperature or overnight at $4{ }^{\circ} \mathrm{C}$. Myelin basic protein (MBP) staining was carried out using a 1:50 dilution of rat anti-MBP (82-87) (Serotec). A 1:100 dilution of mouse anti-2',3'-cyclic nucleotide 3'-phosphohydrolase (CNPase clone 11-5B, Sigma) was used for $\mathrm{CNPase}$ staining. For enhanced green fluorescence protein (EGFP) staining rabbit anti-GFP IgG $(1 \mu \mathrm{g} / \mathrm{mL}$ corresponding to 1:1000, Molecular Probes) was used. After washing with PBS, the cells were incubated with secondary antibodies (Jackson ImmunoResearch Laboratories INC.) diluted 1:100 in PBS with 1\% NGS for $1 \mathrm{~h}$ at room temperature.

\section{RT-PCR and Western blotting}

Total RNA was isolated from oligodendrocyte precursor cells and cDNA was made using a first strand cDNA synthesis kit (Amersham) according to the manufacturer's instructions. For the RT-PCR the primer sequences were: ADAM9 (control) GCCTGACGAAGCCTACA and GTCCACGCTTCCTCCTAT; R-Ras GGTTGGGAACAAGGCAGATC and GCAGGACACAGGGACATCC. For western blotting, differentiated oligodendrocytes were lysed and scraped off in $250 \mu \mathrm{L}$ lysis buffer ( $50 \mathrm{mM}$ Tris- $\mathrm{HCl}, 5 \mathrm{mM}$ EDTA, $150 \mathrm{mM} \mathrm{NaCl}, 1 \%$ Triton X-100, pH7.4), with the protease inhibitors phenylmethylsulfonyl fluoride (2
$\mathrm{mM})$, pepstatin $(1 \mu \mathrm{g} / \mathrm{mL})$, leupeptin $(5 \mu \mathrm{g} / \mathrm{mL})$ and aprotinin $(2 \mu \mathrm{g} / \mathrm{mL}))$ per $10 \mathrm{~cm}$ tissue culture dish. The cell lysates were incubated for $30 \mathrm{~min}$ and centrifuged $(13,000 \mathrm{rpm})$ for $10 \mathrm{~min}$ at room temperature. Protein concentrations were determined using a detergent compatible Lowry protein assay (BioRad DcProtein assay). Denatured, boiled proteins were separated by SDS-PAGE (12\% pre-cast Tris-HCl minigels; BioRad) and transferred onto a $0.45 \mu \mathrm{m}$ nitrocellulose membrane (HybondC, Amersham). The membrane was blocked in $4 \%$ bovine serum albumin (Sigma) in TBST (TBS with $0.1 \%$ Tween 20) for $1 \mathrm{~h}$ at room temperature, and further incubated with rabbit anti-R-Ras (BD PharMingen; 1:1000) in blocking buffer overnight at $4^{\circ} \mathrm{C}$. After washing with TBST, the membrane was incubated with a horseradish peroxidaseconjucated secondary antibody (Amersham) in $2 \%$ blocking buffer for $1 \mathrm{~h}$ at room temperature. The membrane was washed and the immunoreactive proteins were detected using enhanced chemiluminescence (Amersham).

\section{Scoring}

$\mathrm{MBP}+/ \mathrm{EGFP}+$ cells were assigned to one of three morphological categories. Cells that had only primary processes were assigned to the first category, which was denoted 'simple processes'. Cells with secondary and tertiary processes were assigned to a second category denoted 'complex processes'. Cells with myelin sheets (as evidenced by continuous staining filling in between the processes) were assigned to a third category denoted 'myelin sheets'. In each assay, $50 \mathrm{MBP}+$ /EGFP+ oligodendrocytes were scored, with the results being the $\mathrm{M} \pm$ SEM of 3 independent experiments.

\section{Authors' contributions}

IMO carried out all experimental analyses and drafted the manuscript. C ff-C conceived of the study, participated in its design and coordination and helped to draft the manuscript. Both authors read and approved the final manuscript.

\section{Acknowledgements}

We are grateful to Alan Hall (UCL) for providing the R-Ras constructs from which the expression constructs used in this study was made, to Claire

Acquaviva (Cambridge) for the pEGFP-CI expression vector, to John Ivins (Houston) for much helpful advice on integrin activation and to the ffrenchConstant lab for helpful comments on the manuscript. The study was funded by the Danish Research Agency and the Wellcome Trust.

\section{References}

I. ffrench-Constant C, Colognato H, Franklin RJ: Neuroscience. The mysteries of myelin unwrapped. Science 2004, 304(567 I):688-689.

2. Hynes RO: Integrins: versatility, modulation, and signaling in cell adhesion. Cell 1992, 69(I): I I-25.

3. Hynes RO: Integrins: bidirectional, allosteric signaling machines. Cell 2002, I I 0(6):673-687. 
4. Liddington RC, Ginsberg MH: Integrin activation takes shape. J Cell Biol 2002, I 58(5):833-839.

5. Giancotti FG: A structural view of integrin activation and signaling. Dev Cell 2003, 4(2): |49-|5|.

6. Xiao T, Takagi J, Coller BS, Wang JH, Springer TA: Structural basis for allostery in integrins and binding to fibrinogen-mimetic therapeutics. Nature 2004, 432(70 I3):59-67.

7. Mould AP, Humphries MJ: Cell biology: adhesion articulated. Nature 2004, 432(70 I 3):27-28.

8. Milner R, ffrench-Constant C: A developmental analysis of oligodendroglial integrins in primary cells: changes in alpha vassociated beta subunits during differentiation. Development 1994, I 20(1 2):3497-3506.

9. Milner R, Frost E, Nishimura S, Delcommenne M, Streuli C, Pytela R, ffrench-Constant $C$ : Expression of alpha vbeta3 and alpha vbeta8 integrins during oligodendrocyte precursor differentiation in the presence and absence of axons. Glia 1997 2I(4):350-360.

10. Milner R, Edwards G, Streuli C, ffrench-Constant $C$ : $A$ role in migration for the alpha $\mathrm{V}$ beta $\mathrm{I}$ integrin expressed on oligodendrocyte precursors. J Neurosci 1996, I6(22):7240-7252.

II. Blaschuk KL, Frost EE, ffrench-Constant $\mathrm{C}$ : The regulation of proliferation and differentiation in oligodendrocyte progenitor cells by alphaV integrins. Development 2000, I 27(9): I96 I-1969.

12. Buttery PC, ffrench-Constant C: Laminin-2/integrin interactions enhance myelin membrane formation by oligodendrocytes. Mol Cell Neurosci 1999, I4(3): 199-2 I 2.

13. Frost EE, Buttery PC, Milner R, ffrench-Constant C: Integrins mediate a neuronal survival signal for oligodendrocytes. Curr Biol 1999, 9(2I): |25I-I 254.

14. Colognato H, Baron W, Avellana-Adalid V, Relvas JB, Evercooren AB, Georges-Labouesse E, ffrench-Constant C: CNS integrins switch growth factor signalling to promote target-dependent survival. Nat Cell Biol 2002, 14:14.

15. Relvas JB, Setzu A, Baron W, Buttery PC, LaFlamme SE, Franklin RJ, ffrench-Constant $C$ : Expression of dominant-negative and chimeric subunits reveals an essential role for betal integrin during myelination. Curr Biol 200 I, I I ( I3): I039-1043.

16. Ruoslahti $E$ : RGD and other recognition sequences for integrins. Annu Rev Cell Dev Biol 1996, I 2:697-7I5.

17. Zhang Z, Vuori K, Wang H, Reed JC, Ruoslahti E: Integrin activation by R-ras. Cell 1996, 85(I):6I-69.

18. Ivins JK, Yurchenco PD, Lander AD: Regulation of neurite outgrowth by integrin activation. J Neurosci 2000 20(I7):655I-6560.

19. Self AJ, Caron E, Paterson HF, Hall A: Analysis of R-Ras signalling pathways. J Cell Sci 200I, I I 4(Pt 7): I357-1366.

20. Powell SK, Williams CC, Nomizu M, Yamada Y, Kleinman HK: Laminin-like proteins are differentially regulated during cerebellar development and stimulate granule cell neurite outgrowth in vitro. J Neurosci Res 1998, 54(2):233-247.

21. Baron W, Shattil SJ, ffrench-Constant C: The oligodendrocyte precursor mitogen PDGF stimulates proliferation by activation of alpha(v)beta3 integrins. Embo J 2002, 2 I(8): 1957-1966.

22. Byzova TV, Goldman CK, Pampori N, Thomas KA, Bett A, Shattil SJ, Plow EF: A mechanism for modulation of cellular responses to VEGF: activation of the integrins. Mol Cell 2000, 6(4):85I-860.

23. Huai J, Drescher U: An ephrin-A-dependent signaling pathway controls integrin function and is linked to the tyrosine phosphorylation of a I20-kDa protein. J Biol Chem 200I, 276(9):6689-6694.

24. Davy A, Robbins SM: Ephrin-A5 modulates cell adhesion and morphology in an integrin-dependent manner. Embo J 2000, I 9(20):5396-5405.

25. Serini G, Valdembri D, Zanivan S, Morterra G, Burkhardt C, Caccavari F, Zammataro L, Primo L, Tamagnone L, Logan M, et al.: Class 3 semaphorins control vascular morphogenesis by inhibiting integrin function. Nature 2003, 424(6947):391-397.

26. Tadokoro S, Shattil SJ, Eto K, Tai V, Liddington RC, de Pereda JM, Ginsberg MH, Calderwood DA: Talin binding to integrin beta tails: a final common step in integrin activation. Science 2003 , 302(5642): $103-106$.

27. Durand $B$, Raff $M$ : A cell-intrinsic timer that operates during oligodendrocyte development. Bioessays 2000, 22(I):64-71.
28. Garratt AN, Voiculescu O, Topilko P, Charnay P, Birchmeier C: A dual role of erbB2 in myelination and in expansion of the schwann cell precursor pool. J Cell Biol 2000, I 48(5): I 035- 1046.

29. Michailov GV, Sereda MW, Brinkmann BG, Fischer TM, Haug B, Birchmeier C, Role L, Lai C, Schwab MH, Nave KA: Axonal neuregulin-I regulates myelin sheath thickness. Science 2004, 304(567I):700-703. Epub 2004 Mar 2025

30. Chun SJ, Rasband MN, Sidman RL, Habib AA, Vartanian T: Integrinlinked kinase is required for laminin-2-induced oligodendrocyte cell spreading and CNS myelination. J Cell Biol 2003, 163(2):397-408.

31. Franklin RJ: Why does remyelination fail in multiple sclerosis? Nat Rev Neurosci 2002, 3(9):705-7/4.
Publish with Biomed Central and every scientist can read your work free of charge

"BioMed Central will be the most significant development for disseminating the results of biomedical research in our lifetime. "

Sir Paul Nurse, Cancer Research UK

Your research papers will be:

- available free of charge to the entire biomedical community

- peer reviewed and published immediately upon acceptance

- cited in PubMed and archived on PubMed Central

- yours - you keep the copyright

Submit your manuscript here:

http://www.biomedcentral.com/info/publishing_adv.asp
BioMedcentral 